\title{
Siegesbeckia glabrescens induces apoptosis with different pathways in human MCF-7 and MDA-MB-231 breast carcinoma cells
}

\author{
SOO YOUNG JUN ${ }^{1}$, YUNG HYUN CHOI ${ }^{2}$ and HEUNG MOOK SHIN ${ }^{1}$ \\ ${ }^{1}$ Department of Physiology, College of Oriental Medicine, Dongguk University, Kyongju 780-714; ${ }^{2}$ Department of \\ Biochemistry, College of Oriental Medicine, Dongeui University, Busan 614-054, South Korea
}

Received January 19, 2006; Accepted March 9, 2006

\begin{abstract}
Breast cancer is one of the most common malignancies diagnosed in women and it is increasing in incidence. Siegesbeckia glabrescens (SG) has been used in traditional oriental medicine to treat cardiovascular diseases such as hypertension and angina pectoris. This study examined whether or not SG could induce apoptosis in human breast carcinoma cells. The treatment of estrogen-receptor (ER)positive (MCF-7) and ER-negative (MDA-MB-231) cells with a variety of SG concentrations $(0-1.0 \mathrm{mg} / \mathrm{ml})$ resulted in a dose-dependent sequence of events that were marked by apoptosis. Furthermore, this apoptosis was accompanied by the cleavage of procaspase- 9 and -3 , and poly(ADP-ribose) polymerase (PARP) in the MCF-7 cells, and procaspase- 8 and -3 and PARP in the MDA-MB-231 cells. Although, the SG-induced apoptosis was associated with a decrease in the level of Bcl-2 mRNA expression and an increase in the level of Bax mRNA expression in MCF-7 cells, there was no detectable change in the MDA-MB-231 cells. This suggests that SG might exert anti-proliferative action in human breast carcinoma cells via two different apoptotic pathways, namely an intrinsic signal in MCF-7 cells and an extrinsic signal in MDA-MB-231 cells. Therefore, regardless of the ER status, SG might be a promising pro-apoptotic agent for treating breast cancer.
\end{abstract}

\section{Introduction}

Breast cancer is the most common malignancy in American, northwestern European and South Korean women with an increasing incidence in industrialized nations. Approximately $60 \%$ of diagnosed breast cancers are estrogen receptor (ER)positive (1). ER-positive breast cancers generally have a better prognosis and often respond to anti-estrogen therapy,

Correspondence to: Dr Heung M. Shin, Department of Physiology, College of Oriental Medicine, Dongguk University, Sukjangdong, Kyongju 780-714, South Korea

E-mail: heungmuk@dongguk.ac.kr

Key words: Siegesbeckia glabrescens, apoptosis, breast cancer cells, caspase, Bax, Bcl-2 which is the first successful treatment that targets a specific protein, ER $(2,3)$. Unfortunately, ER-negative breast cancer is more aggressive and generally unresponsive to anti-estrogens (4).

Apoptosis is essential for balancing breast epithelial cell homeostasis with cell proliferation. It is defined as genetically programmed cell death and occurs in healthy breast cells at rates that vary during the estrus cycle as a response to hormonal changes (5). Mutations in apoptotic regulatory mechanisms can result in an increase in the number of cells, and the preservation of these genetically altered cells is the initial stage in tumorigenesis (6). Many studies strongly suggest the induction of apoptosis as the means by which chemotherapeutic drugs kill the target breast cancer cells $(7,8)$. The efficacy of these unrelated chemotherapeutic drugs could be modified according to the biochemical alterations that make the cells more or less susceptible to apoptosis $(9,10)$.

There are reports that suggest herbal medicines might be effective against cancer and reduce the level of resistance to chemotherapy (11-13). Siegesbeckia glabrescens (SG) has been used in traditional oriental medicine for centuries to treat hypertension, osteoporotic fractures, guadriplegia, paralysis, and hemiplegia. In addition, SG has been shown to have anti-allergic activity by inhibiting the production of immunoglobulin (Ig) E in lipopolysaccharide-stimulated murine whole spleen cells and human IgE-bearing B cells (14). However, the anti-tumor activity and mechanisms of SG on human cancer cells have never been reported.

Therefore, this study examined whether or not SG could inhibit the growth of ER-positive (MCF-7) and ER-negative (MDA-MB-231) human breast carcinoma cells, regardless of their ER status. In addition, the biochemical steps linking SG to the apoptotic process in these cells were investigated.

\section{Materials and methods}

Preparation of Siegesbeckia glabrescens (SG) extract. The water extract was prepared by mixing $200 \mathrm{~g} \mathrm{SG}$ with $1,000 \mathrm{ml}$ of distilled water and heating the mixture to $70^{\circ} \mathrm{C}$ under reflux for $90 \mathrm{~min}$. The extract was then filtered through a filter paper (Advantec no. 2; Toyo Roshi Kaisha, Japan), and the filtrate was concentrated to approximately $100 \mathrm{ml}$ using a rotary evaporator (Heidolph, Germany) at $70^{\circ} \mathrm{C}$ under vacuum. The residue was then freeze-dried (Hetosicc, Denmark). The yield of the dried extract was approximately $22.28 \mathrm{~g} / \mathrm{l}$. 
A) $\mathrm{MCF}-7$

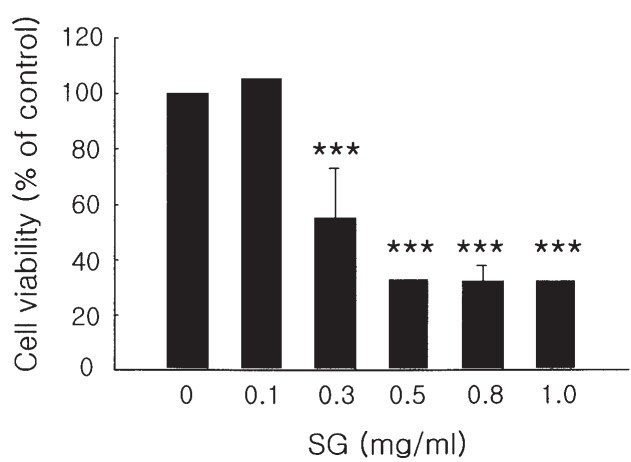

B) $M D A-M B-231$

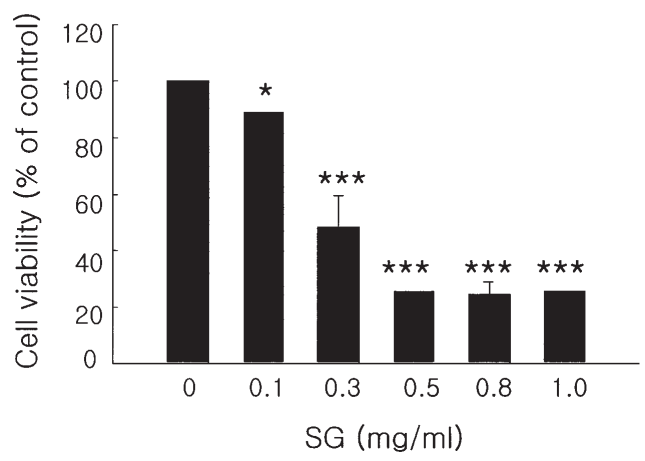

Figure 1. Effects of SG on the cell viability in MCF-7 (A) and MDA-MB-231 (B) cell lines. Each cell line (10x10 4 cells/ml) was incubated with different SG concentrations for $24 \mathrm{~h}$. The cell viability was measured by XTT assay, as described in Materials and methods. The data was obtained from three (MCF-7) and four (MDA-MB-231) independent triplicate experiments. The values are reported as a mean \pm S.D. ${ }^{*}$ p $<0.05$ and ${ }^{* * *}$ p $<0.0001$ compared with the control group.

Cell lines and culture. Human MCF-7 and MDA-MB-231 breast carcinoma cell lines were obtained from the American Type Culture Collection (Rockville, MD, USA) and Korean Cell Line Bank (Seoul, South Korea), respectively. The cells were grown in Dulbecco's modified Eagle's medium (DMEM; Gibco Lab., Grand Island, NY, USA) supplemented with 10\% heat-inactivated fetal bovine serum (FBS; Morgate, Australia), $2 \mathrm{mM}$ L-glutamine and $1 \%$ penicillin-streptomycin (Gibco) in a humidified incubator $\left(5 \% \mathrm{CO}_{2}\right.$ in air at $\left.37^{\circ} \mathrm{C}\right)$.

Cell viability assay. The cells $\left(10 \times 10^{4}\right.$ cells $\left./ \mathrm{ml}\right)$ were seeded into a 96-well plate. After $24 \mathrm{~h}$, the cells were washed with PBS and cultured with serum-free media for a further $20 \mathrm{~h}$. The cells were then treated with $0,0.1,0.3,0.5,0.8$ and $1.0 \mathrm{mg} / \mathrm{ml} \mathrm{SG}$ for $24 \mathrm{~h}$. At the end of the assay time period, $50 \mu 1$ of sodium 3'-[1-(phenylamino-carbonyl)-3,4tetrazolium]-bis(4-methoxy-6-nitro)benzene sulfonic acid hydrate (XTT, Roche Diagnostics, Germany) was added to each well to measure cell viability. After 4-h incubation, the absorbance was measured on an ELISA reader (Bio-Tek Instruments, Winooski, VT, USA) at a wavelength of $490 \mathrm{~nm}$. The background control wells containing the same volume of complete culture medium without cells were also analyzed. The percentage of cell survival was defined as the relative absorbance of untreated cells divided by that of treated cells. For the morphological observation, cells were seeded at a density of $3 \times 10^{5}$ (MCF-7) and $2 \times 10^{5}$ (MDA-MB-231) cells $/ \mathrm{ml}$ containing $2 \mathrm{ml}$ of the medium in 6-well plates for $24 \mathrm{~h}$. The cells were then treated with SG for another $24 \mathrm{~h}$. Morphological changes in the cells were observed using phase-contrast microscopy (Olympus, Japan).

Apoptosis assay. Apoptotic bodies were detected using the following protocol: Untreated and SG-treated cells were washed with PBS and fixed with $3.7 \%$ paraformaldehyde (Sigma-Aldrich, USA) in PBS for $10 \mathrm{~min}$ at room temperature. Fixed cells were washed with PBS, and stained with 4,6diamidino-2-phenylindole (DAPI; Sigma-Aldrich) solution for $10 \mathrm{~min}$ at room temperature. The cells were washed twice more with PBS and analyzed via a fluorescence microscope
(Carl Zeiss, Germany). DNA gel electrophoresis was used to determine the presence of internucleosomal DNA cleavage. Briefly, the cells were treated with $0.3 \mathrm{mg} / \mathrm{ml}$ of SG at the indicated times, which was followed by adding $400 \mu \mathrm{l}$ of a lysis buffer $(0.5 \%$ Triton X-100 in $10 \mathrm{mM}$ EDTA, and $10 \mathrm{mM}$ Tris- $\mathrm{HCl}, \mathrm{pH} 8.0$ ) and incubating the cells for $30 \mathrm{~min}$ on ice. The cells were then separated by centrifugation for $30 \mathrm{~min}$ at $12,000 \mathrm{x}$ g. An equal amount of phenol solution (phenol: chloroform: isoamylalcohol $=25: 24: 1$ ) was added to the supernatant and centrifuged for $1 \mathrm{~min}$ at $12,000 \mathrm{x} \mathrm{g}$. The phenol extraction procedure was repeated three times. After adding 0.1 volume of $3 \mathrm{M}$ sodium acetate, the DNA was precipitated with 2.5 volumes of cold ethanol overnight at $-70^{\circ} \mathrm{C}$. The mixture was centrifuged at $12,000 \mathrm{x}$ g for $10 \mathrm{~min}$, then $700 \mu \mathrm{l}$ of $70 \%$ ethanol was added to the pellet, which was shaken and centrifuged for $1 \mathrm{~min}$ at $12,000 \mathrm{x} \mathrm{g}$. The pellet was treated with $30 \mu \mathrm{g} / \mu \mathrm{l}$ RNase A at $37^{\circ} \mathrm{C}$ for $4 \mathrm{~h}$. The DNA purity and concentration were determined by electrophoresis on $1 \%$ agarose gel containing ethidium bromide (EtBr; Sigma), followed by observation under ultraviolet illumination.

Flow cytometric analysis. After the SG treatment, the cells were collected, washed with cold PBS, and fixed in $75 \%$ ethanol at $4^{\circ} \mathrm{C}$ for $30 \mathrm{~min}$. The DNA content of the cells was measured using a DNA staining kit (CycleTest $^{\text {TM }}$ Plus kit; Becton-Dickinson, San Jose, CA, USA). The propidium iodide (PI)-stained nuclear fractions were obtained according to the kit protocol. The fluorescence intensity was determined using a FACScan flow cytometer and analyzed by CellQuest software (Becton-Dickinson).

Western blot analysis. After the SG treatment, the cells $\left(5 \times 10^{5}\right.$ cells $/ \mathrm{ml}$ in 6-well plate) were lysed in an RIPA buffer (10\% NP-40 containing $20 \mu \mathrm{g} / \mu 1 \mathrm{Na}_{3} \mathrm{VO}_{4}, 10 \mu \mathrm{g} / \mu 1$ leupeptin and $10 \mu \mathrm{g} / \mu \mathrm{l}$ aprotinin) and placed on ice for $30 \mathrm{~min}$. After centrifugation at $12,000 \mathrm{x}$ g for $10 \mathrm{~min}$, the supernatants were collected, and the total protein content was determined using a Lowery protein assay reagent. Equivalent amounts of protein were resolved by SDS polyacrylamide gel electrophoresis (SDS-PAGE, 7.5-12.5\%) and transferred to nitrocellulose 


\section{A) $\mathrm{MCF}-7$}
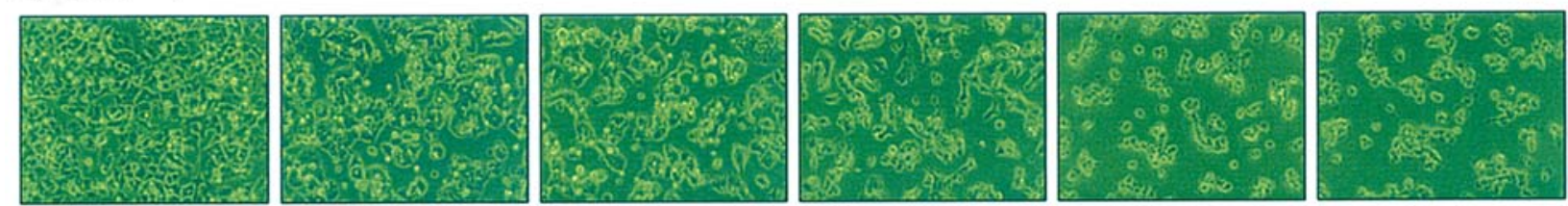

\section{B) $M D A-M B-231$}

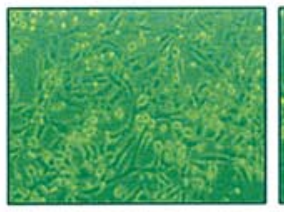

0

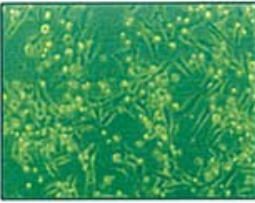

0.1

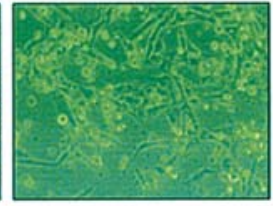

0.3

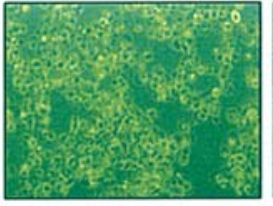

0.5

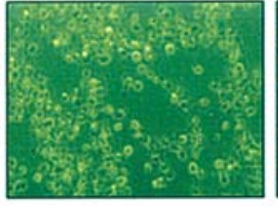

0.8

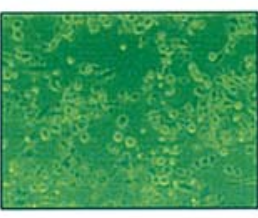

1.0

$\mathrm{SG}(\mathrm{mg} / \mathrm{ml})$

Figure 2. Phase-contrast micrographs of the SG-treated MCF-7 (A) and MDA-MB-231 (B) cells. The cells were treated with indicated concentrations of SG for $24 \mathrm{~h}$. A typical result from three independent experiments is shown (original magnification, x 100).

A)
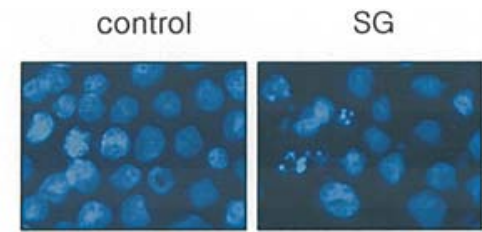

B)

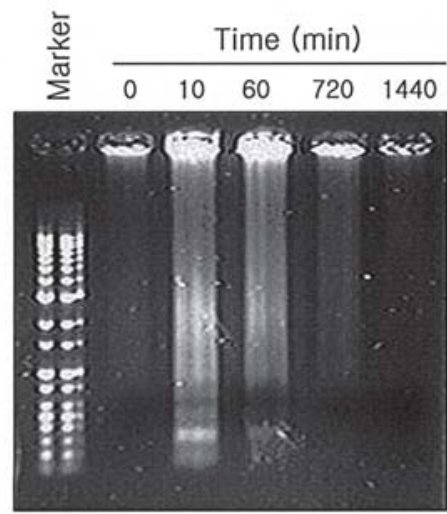

MCF-7 control
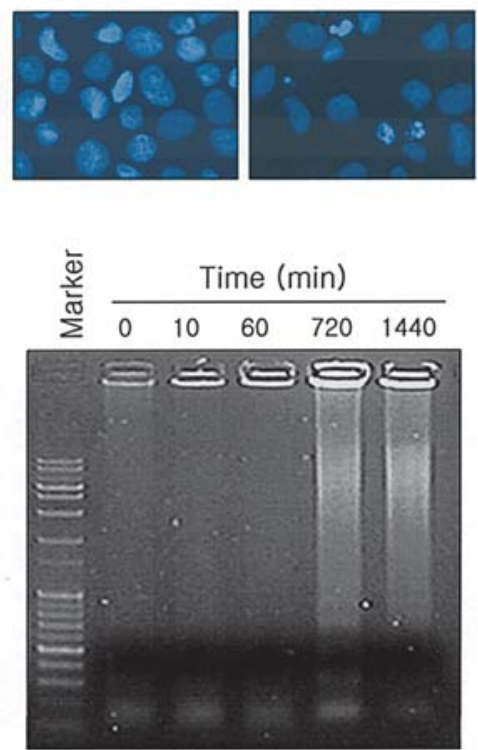

MDA-MB-231

Figure 3. Induction of apoptotic bodies and DNA fragmentation by SG treatment in the MCF-7 and MDA-MB-231 cell lines. (A) Fluorescence microscopic analysis of DAPI staining of MCF-7 and MDA-MB-231 was performed as described in Materials and methods. The cells were examined by fluorescence microscopy. (B) SG $(0.3 \mathrm{mg} / \mathrm{ml})$ induced DNA fragmentation in the MCF-7 and MDA-MB-231 cells. The method for extracting cellular DNA and its electrophoresis on 1\% agarose gels is described in Materials and methods. These results are representative of five (MCF-7) and six (MDA-MB-231) independent experiments.

membranes. The polyclonal antibodies of procaspase-8, -9, and -3 and poly(ADP-ribose) polymerase (PARP) were used as the primary antibodies (Cell Signaling, Beverly, MA, USA). Each protein was detected using enhanced chemiluminescence (ECL) (Amersham Pharmacia Biotech, UK) reagents, and the actin polyclonal antibody was used as the internal control.

cDNA preparation and PCR. RNA was isolated from the treated and untreated cells $\left(5 \times 10^{5}\right.$ cells $/ \mathrm{ml}$ in a 6 -well plate) using Tri-Reagent (Molecular Research Center Inc., Cincinnati, $\mathrm{OH}, \mathrm{USA}$ ), which is an RNA/DNA/protein isolation reagent. The cDNA was then synthesized by reverse transcriptase
(RT) with $0.5 \mu \mathrm{g}$ of oligo dT, 20 units of AMV reverse transcriptase, $1 \mu \mathrm{g}$ of the total cellular RNA, $4 \mu \mathrm{l}$ of $5 \mathrm{X}$ RT buffer, $0.5 \mathrm{mM}$ each $\mathrm{dNTP}$, and $11 \mu \mathrm{l}$ of DEPC. The $20 \mu \mathrm{l}$ reaction mixtures underwent incubation at $65^{\circ} \mathrm{C}$ for $5 \mathrm{~min}$, followed by $42^{\circ} \mathrm{C}$ for $1 \mathrm{~h}$, heating to $95^{\circ} \mathrm{C}$ for $5 \mathrm{~min}$, and rapid chilling on ice. The presence of $\mathrm{Bcl}-2$ and Bax was determined by a polymerase chain reaction (PCR) (MJ Research, Reno, NV, USA) using sequence-specific primers. Glyceraldehyde-3-phosphate dehydrogenase (GAPDH) was used as the internal control to ensure that equal amounts of RNA were used. PCR was carried out in a $1 \mathrm{X}$ reaction buffer containing $0.5 \mathrm{mM}$ dNTP, 10 pmole of the sense and anti-sense 
A) $\mathrm{MCF}-7$

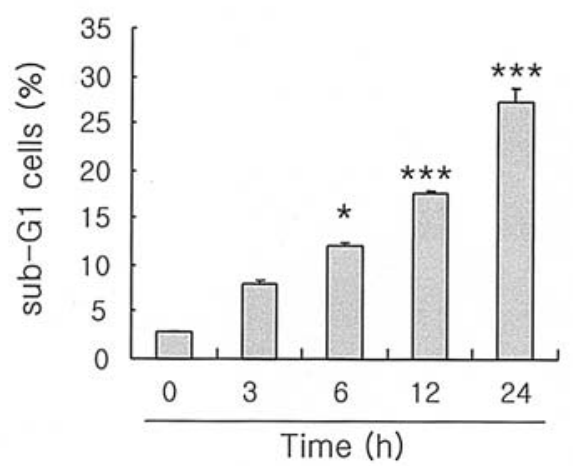

B) $M D A-M B-231$

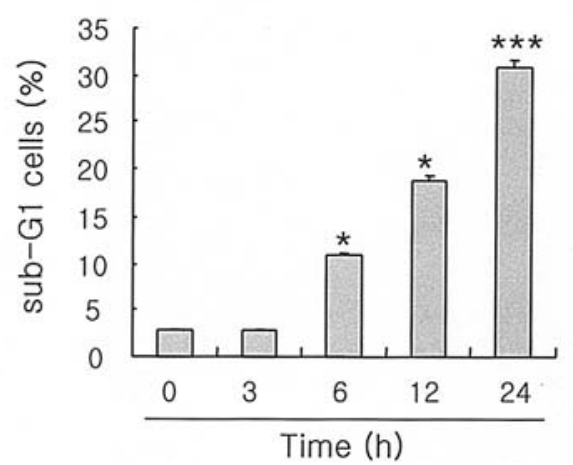

Figure 4. Increase in the sub-G1 cell population as a result of the SG treatment in MCF-7 (A) and MDA-MB-231 (B) cell lines. The cells were treated with $0.5 \mathrm{mg} / \mathrm{ml} \mathrm{SG}$ for the indicated times. The cells were then collected and stained with PI for flow cytometry analysis. The fraction of apoptotic sub-G1 cells is indicated. The values are reported as mean \pm S.D. ${ }^{*} \mathrm{p}<0.05$ and ${ }^{* * *} \mathrm{p}<0.0001$ compared with the control group.

primers for Bcl-2, Bax and GAPDH, $0.5 \mu 1 \mathrm{cDNA}$, and 5 units of Taq DNA polymerase in a $25 \mu 1$ reaction mixture. The PCR profile consisted of 35 (Bcl-2), 32 (Bax), 28 (GAPDH) cycles at $95^{\circ} \mathrm{C}$ for $5 \mathrm{~min}, 95^{\circ} \mathrm{C}$ for $20 \mathrm{sec}, 59^{\circ} \mathrm{C}$ for $40 \mathrm{sec}, 72^{\circ} \mathrm{C}$ for $1 \mathrm{~min}$ and a final extension at $72^{\circ} \mathrm{C}$ for $10 \mathrm{~min}$. The PCR products were analyzed on $1.5 \%$ agarose gel and stained with EtBr. The following primer sequences were used: Bcl-2 forward, 5'-GACAACCGGGAGATAGTGAT-3' and reverse, 5'-ACTCAAAGAAGGCCACAATCC-3'; Bax forward, 5'-AC CAAGAAGCTGAGCGAGTGTC-3' and reverse 5'-AGAAA GATGGTCACGGTCTGCC-3'; GAPDH forward, 5'-CCAT GGAGAAGGCTGGGG-3' and reverse, 5'-CAAAGTTGTC ATGGATGACC-3'.

Bands on the gel were scanned as digitalized images, and the areas under the peaks were calculated by densitometric analysis using a computerized digital imaging system. The areas are reported in arbitrary units. The relative expression level was calculated by comparing the expression level of the sample with that of the internal standard (GAPDH). At least a 2-fold decrease in the relative expression level was considered to be reduced, which was verified by repeat RT-PCR assays.

Statistics. Data are expressed as mean \pm SD. The statistical comparisons were made using a sigma plot. Significant differences $(\mathrm{P}<0.05, \mathrm{P}<0.005$, and $\mathrm{P}<0.0005)$ between the means of the control and SG-treated cells were analyzed using a Student's t-test.

\section{Results}

Cell growth inhibition and morphological changes by SG treatment. The MCF-7 and MDA-MB-231 cell lines were treated with $0-1.0 \mathrm{mg} / \mathrm{ml} \mathrm{SG}$ for $24 \mathrm{~h}$ to determine whether $\mathrm{SG}$ caused a decrease in the number of cells. Fig. 1 shows that the SG treatment inhibited cell growth in a dose-dependent manner, as determined by the XTT assay. At $24 \mathrm{~h}$, the maximum effect was observed with $0.8 \mathrm{mg} / \mathrm{ml} \mathrm{SG}$, which inhibited the proliferation of MCF-7 and MDA-MB-231 cells by $67.7 \%$ (Fig. 1A) and $75.7 \%$ (Fig. 1B), respectively. This anti-proliferative effect of the SG treatment was associated with nuclear and cytosol shrinkage (Fig. 2), which were determined to be apoptotic events (16).
$S G$ treatment induced apoptotic bodies and DNA fragmentation. The nuclear morphological changes associated with apoptosis were analyzed using DAPI staining (15). Fig. 3A revealed the presence of fragmented nuclei characteristic of apoptosis after the SG treatment. In addition, a ladder-like pattern of DNA fragmentation using agarose gel electrophoresis was observed at 10 and 720 min after the SG treatment in MCF-7 and MDA-MB-231 cells, respectively (Fig. 3B). We next analyzed the amount of sub-G1 DNA, which contained less DNA than G1 cells, to quantify the degree of apoptotic cells. Flow cytometric analysis indicated that the SG treatment increased accumulation in the sub-G1 phase in a timedependent manner (Fig. 4). Overall, these results demonstrate that the cytotoxic effect observed in response to the SG treatment is associated with the induction of apoptotic cell death.

Effect of SG on procaspase-8, -9, and -3 and PARP cleavage. Currently, there are two known pathways that activate the caspase cascade, the intrinsic and extrinsic pathways. Following the initial activation of caspase- 9 and -8 in the intrinsic and extrinsic pathways (17), respectively, each caspase cleaves procaspase-3, which normally exists as a $32-\mathrm{kDa}$ inactive precursor and its active form, a 17-kDa fragment. Once activated, caspase- 3 proteolytically cleaves the 116-kDa PARP protein into an $85-\mathrm{kDa}$ fragment, which is considered to be a biochemical characteristic of apoptosis. Western blot analysis results showed that $\mathrm{SG}$ induced the down-regulation of procaspase-8 in MDA-MB-231 cells, but not in MCF-7 cells. On the other hand, procaspase- 9 was down-regulated in MCF-7 cells, but not in MDA-MB-231 cells (Fig 5). SG induced the proteolytic cleavage of procaspase-3 and PARP into their respective active forms, as shown in Fig. 5.

$S G$ changed the ratio of Bcl-2 and Bax mRNA expression. Among Bcl-2 family members, the Bcl-2 and Bax expression ratio might be a key factor in regulating the apoptotic process $(18,19)$. Therefore, the MCF-7 and MDA-MB-231 cells were treated with $0.5 \mathrm{mg} / \mathrm{ml}$ of $\mathrm{SG}$ at the times shown in Fig. 6 . RT-PCR analysis was used to determine the ratio of $\mathrm{Bcl}-2$ and Bax mRNA expression. As shown in Fig. 6, the SG treatment decreased the level of $\mathrm{Bcl}-2$ mRNA expression in 
A) $\mathrm{MCF}-7$

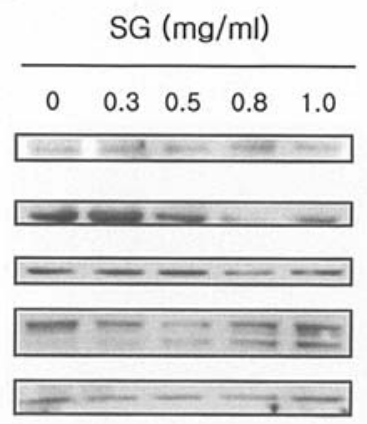

B) $M D A-M B-231$

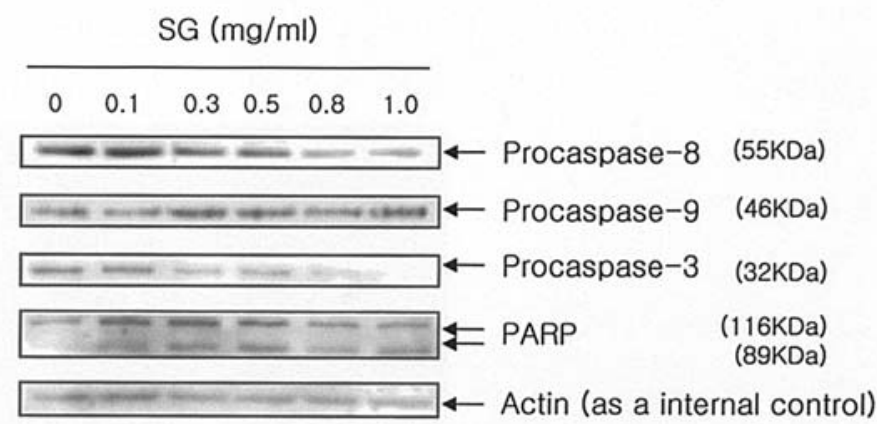

Figure 5. Western blot analysis of the procaspase-8, -9, and -3 and PARP protein levels in MCF-7 (A) and MDA-MB-231 (B) cells exposed to SG. After 24-h incubation with SG, the cells were lysed. The cellular proteins were then separated by $10 \%$ SDS-polyacrylamide gels and transferred onto nitrocellulose membranes. Membranes were probed with the indicated antibodies, and proteins were visualized using an ECL detection system. Actin was used as the internal control. A typical result from four independent experiments is shown.

A)

B)
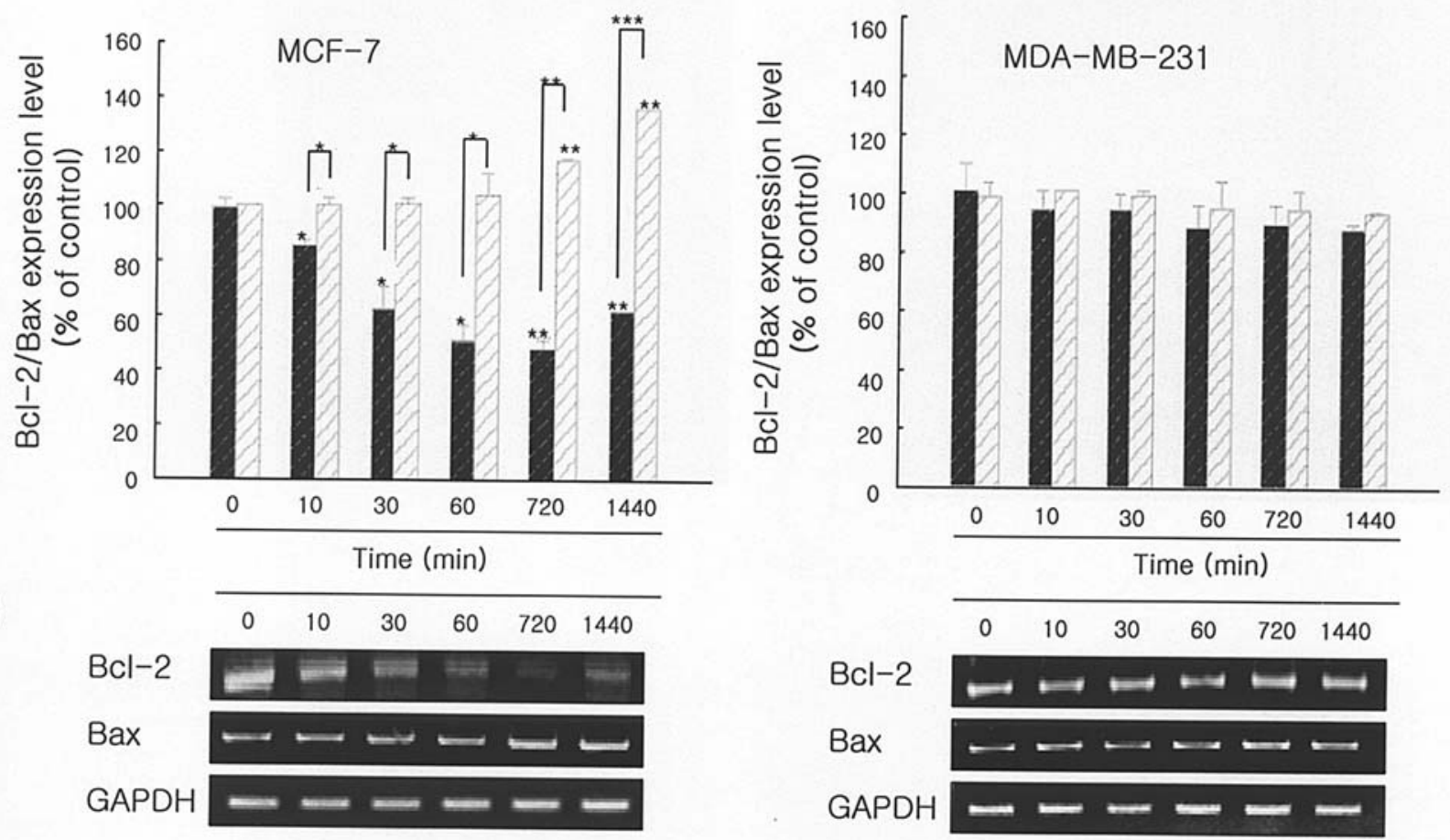

Figure 6. RT-PCR analysis of Bcl-2 and Bax mRNA levels after exposure to SG in MCF-7 and MDA-MB-231 cells. The cells were treated with 0.5 mg/ml of SG for indicated times. (A and B) The Bcl-2 and Bax mRNA ratio in MCF-7 (A) and MDA-MB-231 (B) cells were measured using densitometric analysis. (C and D) Representative Bcl-2 and Bax mRNA expression on MCF-7 (C) and MDA-MB-231 (D) cells. The total RNAs were isolated and reversetranscribed. The resulting cDNAs were subjected to PCR with the Bcl-2 and Bax primers. The reaction products were then subjected to electrophoresis in $1 \%$ agarose gel and visualized by EtBr staining. GAPDH was used as the internal control. A typical result from three independent experiments is shown.

MCF-7 cells, but increased the level of Bax expression. However, in MDA-MB-231 cells, the SG treatment had little effect on the levels of Bcl-2 and Bax expression.

\section{Discussion}

Endocrine therapies, which were first used more than 100 years ago, are the most effective treatments for ER-expressing breast cancers. Selective ER modulators, such as tamoxifen, bind the ER, partially blocking its activity (20). Ovarian ablation, luteinizing hormone-releasing hormone agonists, and aromatase inhibitors reduce the estrogen level and inhibit the ligand-induced activation of the ER $(21,22)$. Steroidal anti-estrogens, such as fulvestrant, bind the ER, block its function more completely, and induce receptor degradation (23). Although many therapies have been developed, most are restricted to ER-expressing breast cancers.

Siegesbeckia glabrescens (SG) is a herbal medicine widely used in South Korea for detoxification and treating arthritis and fever (14). This study first reported the effect of SG in inhibiting cell growth in ER-positive MCF-7 and ER-negative MDA-MB-231 cells. SG induced apoptosis in MCF-7 and 
MDA-MB-231 cells, which was determined by a loss of cell viability, nuclear shrinkage, and apoptotic body formation, as confirmed by the XTT assay, DAPI staining and internucleosomal DNA fragmentation. However, these effects were not observed in healthy human umbilical vein endothelial cells (data not shown). This suggests that SG specifically inhibits cell growth and induces apoptotic cell death in breast cancer cell lines.

Apoptosis is essential for the development and maintenance of life. It is currently defined as a discrete sequence of morphological changes leading to cell death with extensive dsDNA cleavage accompanied by chromatin compaction and segregation along the nuclear membrane $(5,6)$. It has been reported that apoptosis contributes to cell death in tumors treated with various anti-carcinoma agents. Moreover, most developed chemotherapeutic agents (Prodigiosin, Cimicifuga racemosa, Antrodia camphorata, et al), which originate from natural products, reportedly induce apoptosis in breast cancer cells $(10,24,25)$.

Currently, there are two known pathways that can activate the caspase cascade. The intrinsic pathway involves the Bcl-2 family of proteins and the release of cytochrome $\mathrm{c}$ from the mitochondria (26-28). Once released, cytochrome c binds to the Apaf-1 adaptor protein, which then activates procaspase-9 in a dATP-dependent reaction leading to procaspase- 3 activation. The extrinsic pathway is independent of the mitochondria and is induced by the death receptor-protein complexes that cleave procaspase-8 (29). The cleavage and activation of caspase- 8 initiates the caspase cascade. Following the initial induction, the intrinsic and extrinsic pathways merge at the caspase- 3 level. At the onset of apoptosis, activated caspase- 3 degrades the PARP protein (30).

This study examined the apoptotic pathways resulting from the SG treatment in human MCF-7 and MDA-MB-231 breast carcinoma cell lines. The results showed that SG induced apoptosis via the cleavage of procaspase- 9 and -3 and PARP in MCF-7 cells, and cleavage of procaspase- 8 and -3 and PARP in MDA-MB-231 cells. This suggests that, after the addition of SG, the extrinsic pathway might be involved in MCF-7 apoptosis, and the intrinsic pathway plays a role in MDA-MB-231 apoptosis.

The Bcl-2 family consists of a number of both antiapoptotic (Bcl-2, Bcl-XL, Mcl-1, Bfl-1/A1, Bcl-W and Bcl-G) and proapoptotic (Bax, Bak, Bok, Bad, bid, Bik, Bim, BclXS, Krk, Mtd, Nip3, Noxa and Bcl-B) proteins $(31,32)$. Expression and dimerization of the Bcl-2 family proteins influence cellular sensitivity to apoptosis by regulating the release of cytochrome $\mathrm{c}$, which precedes caspase activation $(18,19)$. In this study, SG dramatically decreased the level of Bcl-2 mRNA expression and increased the level of Bax mRNA expression in MCF-7 cells. However, there was no detectable change in the levels of $\mathrm{Bcl}-2$ and Bax mRNA expression in MDA-MB-231 cells.

In conclusion, $\mathrm{SG}$ has an anti-proliferative effect in both ER-positive MCF-7 and ER-negative MDA-MB-231 cells by inducing apoptosis. The molecular mechanisms of the apoptotic effect by SG are: i) degradation of procaspase-9 and -3 and PARP in MCF-7 cells; ii) cleavage of procaspase- 8 and -3 and PARP in MDA-MB-231 cells; iii) a decrease in the level of Bcl-2 expression and an increase in the level of Bax mRNA expression in MCF-7 cells; and iv) no detectable change in the levels of Bcl-2 and Bax mRNA expression in MDA-MB-231 cells. These results highlight SG as a promising chemopreventive agent, particularly for estrogen receptor-negative breast cancers, which have a poorer prognosis and shorter survival. However, further investigation is needed to determine the active components in SG along with the mechanisms for its action on human breast carcinomas.

\section{References}

1. Lippman ME: Endocrine responsive carcinomas of man. In: Textbook of Endocrinology. Williams RH (ed). WB Saunder Corp., Philadelphia, pp1309-1326, 1985.

2. Jordan VC and Murphy CS: Endocrine pharmacology of antiestrogens as antitumor agents. Endocr Rev 11: 578-610, 1990.

3. Rochefort H, Capony F, Garcia M, Cavailles V, Freiss G, Chambon M, Morisset M and Vignon F: Estrogen-induced lysosomal proteases secreted by breast cancer cells. A role in carcinogenesis? J Cell Biochem 35: 17-29, 1987.

4. Sheikh MS, Garcia M, Pujol P, Fontana JA and Rochefort H: Why are estrogen-receptor-negative breast cancers more aggressive than the estrogen-receptor-positive breast cancers? Invasion Metastasis 14: 329-336, 1995.

5. Wu J: Apoptosis and angiogenesis: two promising tumor markers in breast cancer. Anticancer Res 16: 2233-2240, 1996.

6. Furth PA: Apoptosis and the development of breast cancer. In: Breast Cancer: Molecular Genetics, Pathogenesis, and Therapeutics. Bowcock AM (ed). Humana Press, New Jersey, pp171-180, 1999.

7. Chien ALT and Pihie AHL: Styrylpyrone derivative induces apoptosis through the up-regulation of Bax in the human breast cancer cell line MCF-7. J Biochem Mol Biol 36: 269-274, 2003.

8. Candi E, Melino G, Laurenzi VD, Piacentini M, Guerrieri P, Spinedi A and Richard AK: Tamoxifen and somatostatin affect tumours by inducing apoptosis. Cancer Lett 96: 141-145, 1995.

9. Ameyar M, Azeddine A, Zhenzi C, Stancou R, Shatrov V, Bettaieb A and Salem C: Analysis of human breast adenocarcinoma MCF7 resistance to tumor necrosis factor-induced cell death: J Biol Chem 273: 29002-29008, 1998.

10. Soto-Cerrato V, Liagostera E, Montaner B, George LS and Perez-Tomas R: Mitochondria-mediated apoptosis operating irrespective of multidrug resistance in breast cancer cells by the anticancer agent prodigiosin. Biochem Pharmacol 68: 1345-1352, 2004

11. Primchanien M, Nuttavut K, Omboon L, Suna J and Narongchai P: Antiproliferative activity of Thai medicinal plant extracts on human breast adenocarcinoma cell line. Fitoterapia 75: 375-377, 2004.

12. Kenji I, Teru H, Makoto H, Noopur R, Shaji K, Hiromasa H, Norihiko S, Hiroshi Y, Aldo MR, Richardson P, Podar K, Gouill SL, Chauhan D, Tamura K, Arbiser J and Anderson KC: Honokiol overcomes conventional drug resistance in human multiple myeloma by induction of caspase-dependent and independent apoptosis. Blood 106: 1794-1800, 2005.

13. Efferth T, Rose DD, Gebhart E and Neugebauer M: Activity of ascaridol from the anthelmintic herb Chenopodium anthelminticum $L$. against sensitive and multidrug-resistant tumor cells. Anticancer Res 22: 4221-4224, 2002.

14. Kim HM, Lee JH, Won JH, Park EJ, Chae HJ, Kim HR, Kim $\mathrm{CH}$ and Baek SH: Inhibitory effect on immunoglobulin $\mathrm{E}$ production in vivo and in vitro by Siegesbeckia glabrescens. Phytother Res 15: 572-576, 2001.

15. Choi YH, Im EO, Suh HS, Jin YE, Lee WH, Yoo YH, Kim KW and Kim ND: Apoptotic activity of novel bile acid derivatives in human leukemic $\mathrm{T}$ cells through the activation of caspases. Int $\mathbf{J}$ Oncol 18: 979-984, 2001

16. Dini L, Coppola S, Ruzittu MT and Ghibelli L: Multiple pathways for apoptotic nuclear fragmentation. Exp Cell Res 223: 340-347, 1996.

17. Earnshaw WC, Martins LM and Kaufmann SH: Mammalian caspases: Structure, activation, substrates, and functions during apoptosis. Ann Rev Biochem 68: 383-424, 1999. 
18. Lai KL and Thomas TYW: Differential effects of chemotherapeutic agents on the $\mathrm{Bcl}-2 / \mathrm{Bax}$ apoptosis pathway in human breast cancer cell line MCF-7. Breast Cancer Res Treat 55: 73-83, 1999.

19. Tudor G, Aguilera A, Halverson DO, Laing ND and Sausville EA: Susceptibility to drug-induced apoptosis correlates with differential modulation of Bad, Bcl-2 and Bcl-XL protein levels. Cell Death Diff 7: 574-586, 2000.

20. Jordan VC: Selective Estrogen receptor modulation: a personal perspective. Cancer Res 61: 5683-5687, 2001.

21. Geisler J, King N, Anker G, Ornati G, Salle ED, Lonning PE and Dowsett M: In vivo inhibition of aromatization by exemestane, a novel irreversible aromatase inhibitor, in postmenopausal breast carcinoma patients. Clin Cancer Res 4: 2089-2093, 1998.

22. Demers LM: Effects of Fadrozole (CGS 16949A) and letrozole (CGS 20267) on the inhibition of aromatase activity in breast carcinoma patients, Breast Cancer Res Treat 30: 95-102, 1994

23. Robertson JFR, Come SE, Jones SE, Beex L, Kaufmann M, Makris A, Nortier JWR, Possinger K and Rutqvist LE: Endocrine treatment options for advanced breast cancer - the role of fulvestrant. Eur J Cancer 41: 346-356, 2005.

24. Hostanska K, Nisslein T, Freudenstein J, Reichling J and Saller R: Cimicifuga racemosa extract inhibits proliferation of estrogen receptor-positive and negative human breast carcinoma cell lines by induction of apoptosis. Breast Cancer Res Treat 84: 151-160, 2004.
25. Yang HL, Chen CS, Chang WH, Lu FJ, Lai YC, Chen CC, Hseu TH, Kuo CT and Hseu YC: Growth inhibition and induction of apoptosis in MCF-7 breast carcinoma cells by Antrodia camphorate. Cancer Lett (In press).

26. Herr I and Debatin KM: Cellular stress response and apoptosis in cancer therapy. Blood 98: 2603-2614, 2001.

27. Gross A, McDonnell JM and Korsmeyer SJ: Bcl-2 family members and the mitochondria in apoptosis. Genes Dev 13: 1899-1911, 1999.

28. Yang J, Liu X, Bhalla K, Kim CN, Ibrado AM and Cai J: Prevention of apoptosis by Bcl-2: release of cytochrome $\mathrm{c}$ from mitochondria blocked. Science 275: 1129-1132, 1997.

29. Nagata S and Golstein P: The Fas death factor. Science 267: 1449-1456, 1995

30. Nicholson DW, Ali A, Thornberry NA, Vaillancourt JP, Ding CK, Gallant M, Gareau Y, Griffin PR, Labelle M, Lazebnik YA, Munday NA, Raju SM, Smulson ME, Yamin TT, Yu VL and Miller DK: Identification and inhibition of the ICE/CED-3 protease necessary for mammalian apoptosis. Nature 376: 37-43, 1995.

31. Adams JM and Cory S: The Bcl-2 protein family: arbiters of cell survival. Science 281: 1322-1326, 1998.

32. Green DR and Reed JC: Mitochondria and apoptosis. Science 281: 1309-1312, 1998. 